\title{
Making performance analysis of on grid photovoltaic energy systems: Example of Turkey
}

\author{
Ugur Kılıç* and Ugur Kesen** \\ * Department of Electrical Engineering, Ylldız Technical University, Istanbul, Turkey \\ ** Department of Mechatronics Engineering, Technology Faculty, Istanbul Marmara University, Istanbul, 34722, Turkey \\ **Corresponding Author: ugurkilicytu@gmail.com
}

$\begin{array}{ll}\text { Submitted } & : 08 / 05 / 2020 \\ \text { Revised } & : 11 / 04 / 2021 \\ \text { Accepted } & : 18 / 05 / 2021\end{array}$

\begin{abstract}
The globalizing world and the rapid increase in industrialization and urbanization rates have increased the world's need for energy day by day, making energy one of the most important agenda items of the world. Increasing demand has led the countries to ensure supply-demand balance to become one of the basic energy policies. One of these prominent energy policies is to ensure diversity in supply and to turn towards renewable resources that are not dependent on exhausted fossil fuels. One of these renewable sources is photovoltaic (solar cell) energy generation systems that generate electrical energy from solar energy. Solar energy is a good alternative to fossil fuels as it has an environmentally clean source feature. In this study, the performance evaluations of power plants were made by comparing the simulation results with data obtained from established fields in three different geographical regions of Turkey. In addition, regional production efficiency was analyzed by comparing the production values of the plants among themselves. An interface program that analyzes instant power plant values was designed, and a practical evaluation software was created.
\end{abstract}

Keywords: Sun grid solar energy; Photovoltaic energy; Renewable energy, Solar power.

\section{INTRODUCTION}

The demand for energy is increasing day by day. With the increase in demand, concerns about the supplydemand balance started to emerge. The World Energy Forum emphasizes on the rapid depletion of fossil fuels such as oil, natural gas, and coal. According to the forecasts of the forum, these fossil energy resources will be exhausted in the next century. Thus, the supply-demand balance will gradually deteriorate, and this deterioration will lead communities to meet demand from different sources (Kjaer et al., 2005). In addition to the rapid depletion, attention is also drawn to the environmental damage caused by these fuels (Rawat et al.2019). Currently, being used as the primary energy sources, these fuels not only produce energy output with their use, but also threaten human health with harmful gas emissions (Seme et al., 2019). These and similar reasons direct societies to clean and sustainable renewable sources (Yadav et al., 2015). Renewable energy sources have started to find itself an important place in the making of development policies (Andaloussi et al., 2020). In this context, the importance of renewable sources has increased significantly and certainly will increase even more (Dincer., 2011, Olmez., 2017, Gucin., 2013). 
Renewable energy sources are classified as solar, wind, biomass, geothermal, hydraulic, and hydrogen (Al Badi., 2018, Khan et al., 2020, Li et al., 2011). Solar energy (photovoltaic) systems are one of the most prominent of these sources (Cubukcu et al., 2020). Photovoltaic energy systems convert sunlight that hits their surface to electrical energy. (Ismail et al., 2013). Energy producing solar cells are connected in series and in parallel to obtain the desired current, voltage, and power values (Banda et al., 2019, Mofijur et al., 2019). Not only for being able to convert the potential power to installed power, but also for energy efficiency, it is necessary to size and simulate the system parameters. In these simulations, PVsyst program, which has a wide utilization rate and high accuracy, is used (Boateng., 2016). In this context, researchers have conducted extensive studies. In the determination of potential power-performance analysis studies, the PV power that can be generated on or around a structure that is not predetermined or is planned to be built is analyzed. In a study, hourly global solar radiation values on horizontal surface from measured daily global solar radiation values are estimated by using eleven different statistical models (Ayvazogluyuksel, 2016). Other performance analysis studies include the characteristics and development of the photovoltaic systems for climate conditions (Basha., 2012). Another type of performance evaluation study is the comparison of the PV generation capacities of the regions. In these comparisons, field data, simulation results, or both can be examined. Thus, the optimal installation point for PV production facilities can be determined (Sakdiseth., 2015). In this context, both technical and economic evaluations are carried out (Karatas., 2012). The software preference for the analysis is also important for the prediction of power plant efficiencies. One of the commonly used programs for performance estimations is the PVsyst program. In a study conducted in India, the performance of $190 \mathrm{kWp}$ on grid solar PV plant is analyzed using this program (Sharma et al., 2013). The electrical energy produced by PV arrays and their losses in grid connected systems of Kathmandu and Berlin were also analyzed using PVsyst (Karki et al., 2012). Similarly, there are studies reporting advantage of PVsyst to simulate PV systems and manufacture power outputs (Bouhouras et al., 2010, Kandasamy et al., 2013).

This study aimed to compare the data obtained from actual field values of three power plants in operation located in three different regions of Turkey, to determine the overlap between the actual values and PVsyst simulation results and provide insight for optimal investment strategy. In this context, the actual measurement values obtained from three power plants operating in three different regions of Turkey, founded by the same investor with the same technical features and installed power, are compared to PVsyst simulation results, and a performance evaluation was conducted. Thus, efficiency analysis has been provided to investors who plan to invest in three selected regions in Turkey. By determining the overlap ratio between PVsyst simulation and real values, the reliability of the simulation is presented to potential investors. In addition, an analysis interface was designed using Visual Basic software to perform comparative analysis.

\section{METHODOLOGY}

In this study, the data obtained from the operating plants were compared both among themselves and with the simulations from PVsyst. These comparisons were examined together through the designed interface program. In order to perform the data analysis, the updated data received from already established power plants located in Eastern Anatolia, Mediterranean, and Central Anatolia regions of Turkey were used. For each region, plants with an installed power of $1020 \mathrm{KWac}$ in that region were taken as reference. In order to obtain the correct comparison results, the plants that have been installed by the same company using the same products have been selected. All measurements were obtained with 15 minutes measurements using Janitza Brand energy analyzers. It should be specifically stated here that the used energy analyzer's warm-up time is 10 minutes. For this reason, the device shows deviations due to the heating problem in measurements taken under 10 minutes. Therefore, taking into account the datasheet of the device used, it has been determined as a measurement time of 15 minutes. The raw data obtained from the energy analyzer have been translated into meaningful data using the excel work environment. Malatya Province was selected as the reference province for the Eastern Anatolia Region, Niğde Province for the Central Anatolia Region, and Adana Province for the Mediterranean Region. A total of 90 days of data obtained between 7 February-7 May were 
analyzed regionally and individually. 3876 panels were used in the installed power plant in the field. $1124 \mathrm{kWp} \mathrm{DA}$ power production has been accomplished by stringing 19 panels in parallel. A total area of 7521 square meters was used for the modules. Umpp (MPP Voltage) was 610 Volts, and Impp (MPP Current) was 1648 amps. In order to convert DC power to AC power, 17 on grid solar inverters each having a capacity of generating $60 \mathrm{kWac}$ power have been used to establish a system with $1020 \mathrm{kWac}$ installed power. The predictions for the data obtained from the field have been managed using PVsyst program. In order to analyze all these data with ease, an interface program has been designed. The Visual Basic programming language was created with the development of the Basic language, which was developed by Microsoft to create simple programs. The advantages arising from its full connection with Windows have increased its usage over time. It has become the sought-after language for top-level, object-oriented, event-driven, and visual programming. Personal software can be created very easily with the media collector structures called IDE. Visual Basic program is useful for coding, editing these codes, and debugging to make the programs more functional. In addition, improving your program and connecting to a database using it in larger scale works are among the processes that can be done. Basically, this is the simplest answer to the question what Visual Basic can do. It is possible to develop these transactions for commercial programs, special designs for companies, web applications, other platform applications, user interfaces, and reporting applications.

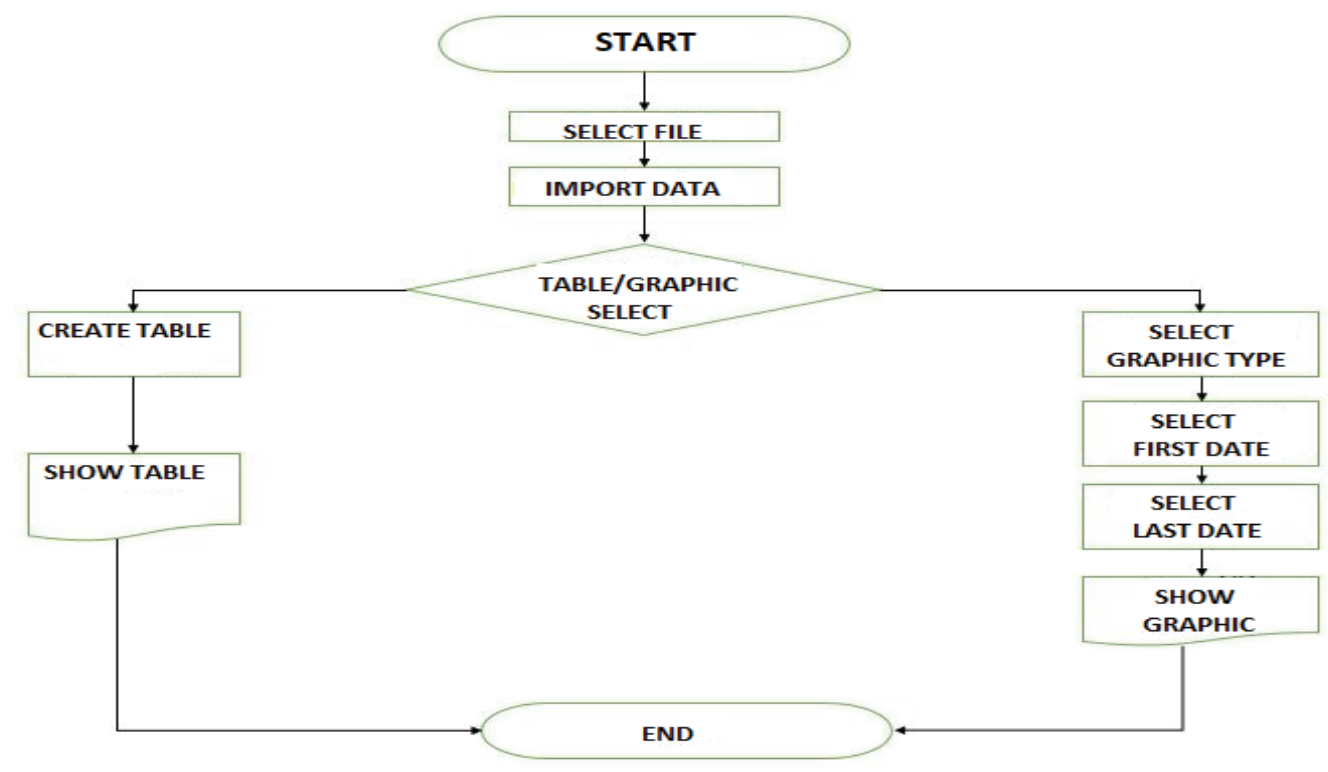

Figure 1. Interface program flow chart.

By using these features of Visual Basic program, we designed an analyzer where we can make power plant analysis. By withdrawing the data over the selected source file, the developed program can analyze the power plant production values in desired date range in table or graph format. The operating system of the program is given in Fig. 1 as a flow chart. After running the program, the selected file tab appears on the screen, and the source file is selected from this tab, and the button is clicked to get information. After the information is withdrawn from source file, it can be visualized in table or graph format. If table button is selected, the output data will be generated in table format. If the data is desired to be visualized as graph, then graph button should be selected. The graph type is selected from the area, line, curve, point, and column tabs and proceeded with the next step, which is the first date tab. After the first date is selected, the last date should be selected as well. The output data is visualized on analyzer screen after the last date is chosen to indicate the time interval of analysis. 


\section{RESULT AND DISCUSSION}

In this section, the production values taken from the fields will be compared among each other and individually. Comparison will be made based on the production differences of plants in 3 different cities and their match rate with the simulation values.

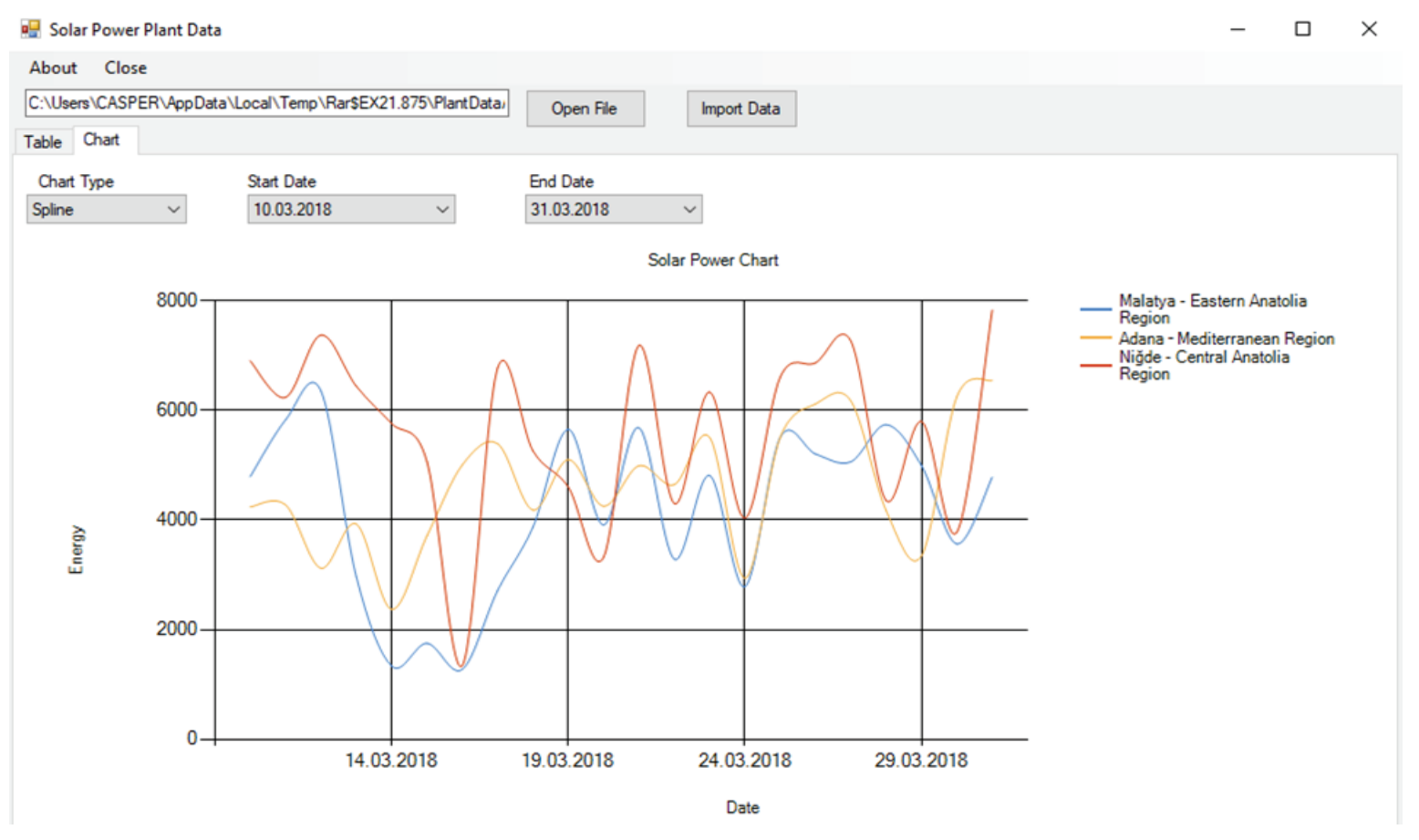

Figure 2. Solar energy data of the regions for February.

In this study, the measured data were selected by determining the dates between 7 February and 7 May. As an example, selected solar energy data for 14-29 March is shown in Fig. 2.

\section{Regional Comparison and Analysis of Actual Production Values}

In February, energy production of power plants located in Malatya, Adana, and Niğde provinces was $72240.0585 \mathrm{kwh}, 71658 \mathrm{kwh}$, and $97418.2103 \mathrm{kwh}$, respectively. In February, energy production values of Malatya and Adana power plants were observed to be close. However, Niğde power plant is at the forefront of production values with a significant difference with its $97418.2103 \mathrm{kwh}$ production value. Likewise, when the data for March was examined, it was observed that the energy produced for Malatya, Adana, and Niğde plants was 114827.9825 kwh, $137567.366 \mathrm{kwh}$, and 156585.2289 kwh, respectively. As in February, Niğde power plant achieved the highest production value in March. In April, the production values were recorded to be $188441.6989 \mathrm{kwh}, 160220.8964 \mathrm{kwh}$, and $196651.0873 \mathrm{kwh}$ for Malatya, Adana, and Niğde power plants, respectively. Among three power plants, Niğde power plant had the highest production value in April with a less significant difference compared to previous months. Based on 7-day long data analysis of May, energy production values of Malatya, Adana, and Niğde were 29788.5228 $\mathrm{kwh}, 37292.2421 \mathrm{kwh}$, and $40107.4055 \mathrm{kwh}$, respectively. When the total energy production values of three power plants were evaluated for the dates between 7 February-7 May, it was observed that $405298.2627 \mathrm{kwh}, 406739.0771$ kwh, and $490762.932 \mathrm{kwh}$ total energy were produced by Malatya, Adana, and Niğde, respectively. 


\section{Comparison and Analysis of Actual Production Values and PVsyst Reports}

In this study, the actual production values were analyzed comparatively with the PVsyst reports. PVsyst simulation outputs for Malatya power plants are shown in Figure 3.

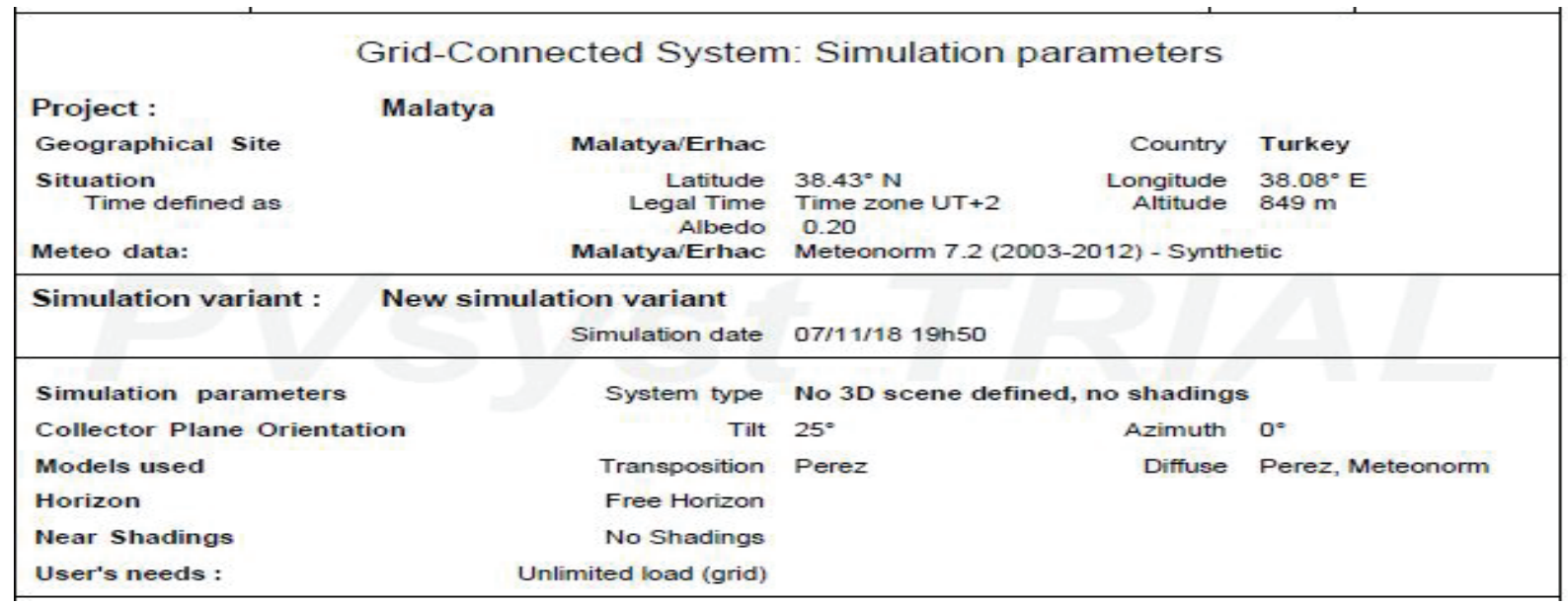

\begin{tabular}{|c|c|c|c|c|}
\hline $\begin{array}{l}\text { PV Array Characteristics } \\
\text { PV module } \\
\text { Original PVsyst database } \\
\text { Number of PV modules } \\
\text { Total number of PV modules } \\
\text { Array global power } \\
\text { Array operating characteristics }\left(50^{\circ} \mathrm{C}\right) \\
\text { Total area }\end{array}$ & $\begin{array}{r}\text { Model } \\
\text { Si-poly Manufacturer } \\
\text { In series } \\
\text { Nb. modules } \\
\text { Nominal (STC) } \\
\text { U mpp } \\
\text { Module area }\end{array}$ & $\begin{array}{l}\text { BYD } 290 \text { P6-36 } \\
\text { BYD } \\
19 \text { modules } \\
3876 \\
1124 \mathrm{kWp} \\
610 \mathrm{~V} \\
7521 \mathrm{~m}^{2}\end{array}$ & $\begin{array}{r}\text { In parallel } \\
\text { Unit Nom. Power } \\
\text { At operating cond. } \\
\text { I mpp } \\
\text { Cell area }\end{array}$ & $\begin{array}{l}204 \text { strings } \\
290 \mathrm{Wp} \\
1005 \mathrm{kWN}\left(50^{\circ} \mathrm{C}\right) \\
1648 \mathrm{~A} \\
6791 \mathrm{~m}^{2}\end{array}$ \\
\hline $\begin{array}{l}\text { Inverter } \\
\text { Original pVsyst database } \\
\text { Characteristics }\end{array}$ & $\begin{array}{r}\text { Model } \\
\text { Manufacturer } \\
\text { Operating Voltage }\end{array}$ & $\begin{array}{l}\text { Sunny Tripower } \\
\text { SMA } \\
570-800 \mathrm{~V}\end{array}$ & $\begin{array}{l}\text { 60-10 } \\
\text { Unit Nom. Power }\end{array}$ & $60.0 \mathrm{kWVac}$ \\
\hline Inverter pack & Nb. of inverters & 17 units & $\begin{array}{l}\text { Total Power } \\
\text { Pnom ratio }\end{array}$ & $\begin{array}{l}1020 \mathrm{kWac} \\
1.10\end{array}$ \\
\hline \multicolumn{5}{|l|}{ PV Array loss factors } \\
\hline Thermal Loss factor & Uc (const) & $20.0 \mathrm{~W} / \mathrm{m}^{2} \mathrm{~K}$ & Uv (wind) & $0.0 \mathrm{~W} / \mathrm{m}^{2} \mathrm{~K} / \mathrm{m} / \mathrm{s}$ \\
\hline $\begin{array}{l}\text { Wiring Ohmic Loss } \\
\text { Module Quality Loss } \\
\text { Module Mismatch Losses } \\
\text { Strings Mismatch loss } \\
\text { Incidence effect, ASHRAE parametriza }\end{array}$ & Global array res. & $6.3 \mathrm{monm}$ & $\begin{array}{l}\text { Loss Fraction } \\
\text { Loss Fraction } \\
\text { Loss Fraction } \\
\text { Loss Fraction } \\
\text { bo Param. }\end{array}$ & $\begin{array}{l}1.5 \% \text { at STC } \\
-0.8 \% \\
1.0 \% \text { at MPP } \\
0.10 \% \\
0.05 \%\end{array}$ \\
\hline
\end{tabular}

New simulation variant

Balances and main results

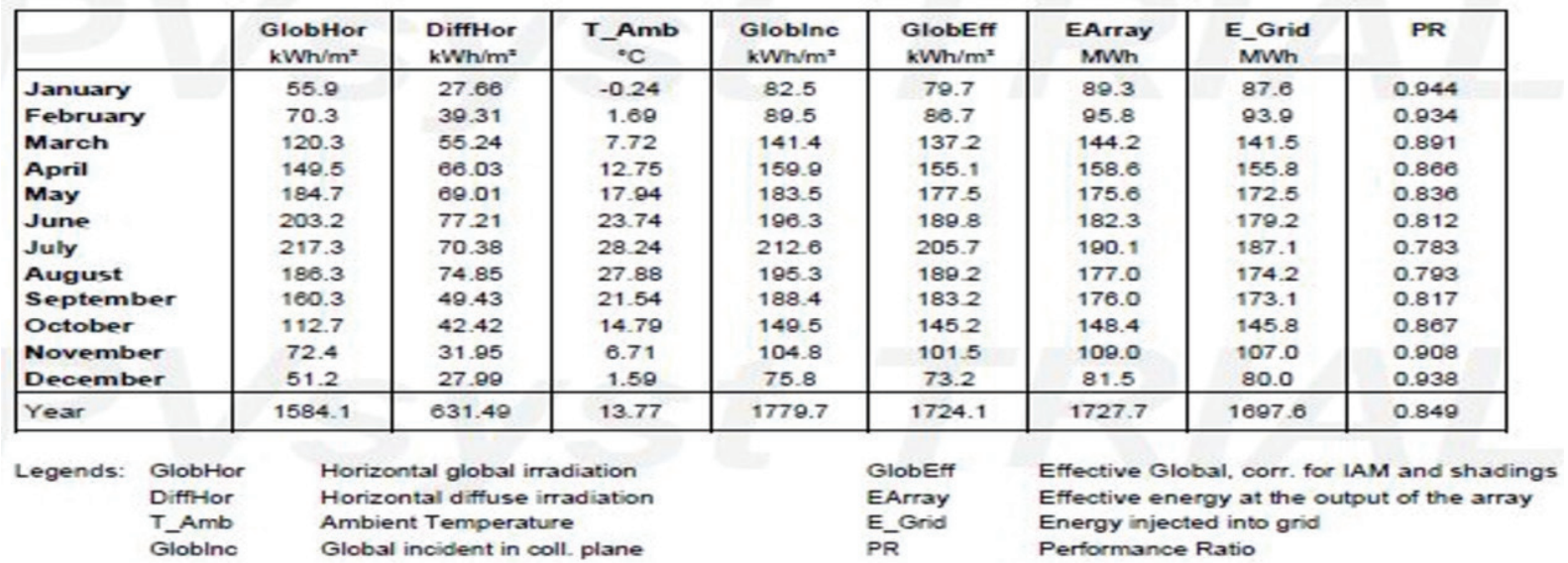




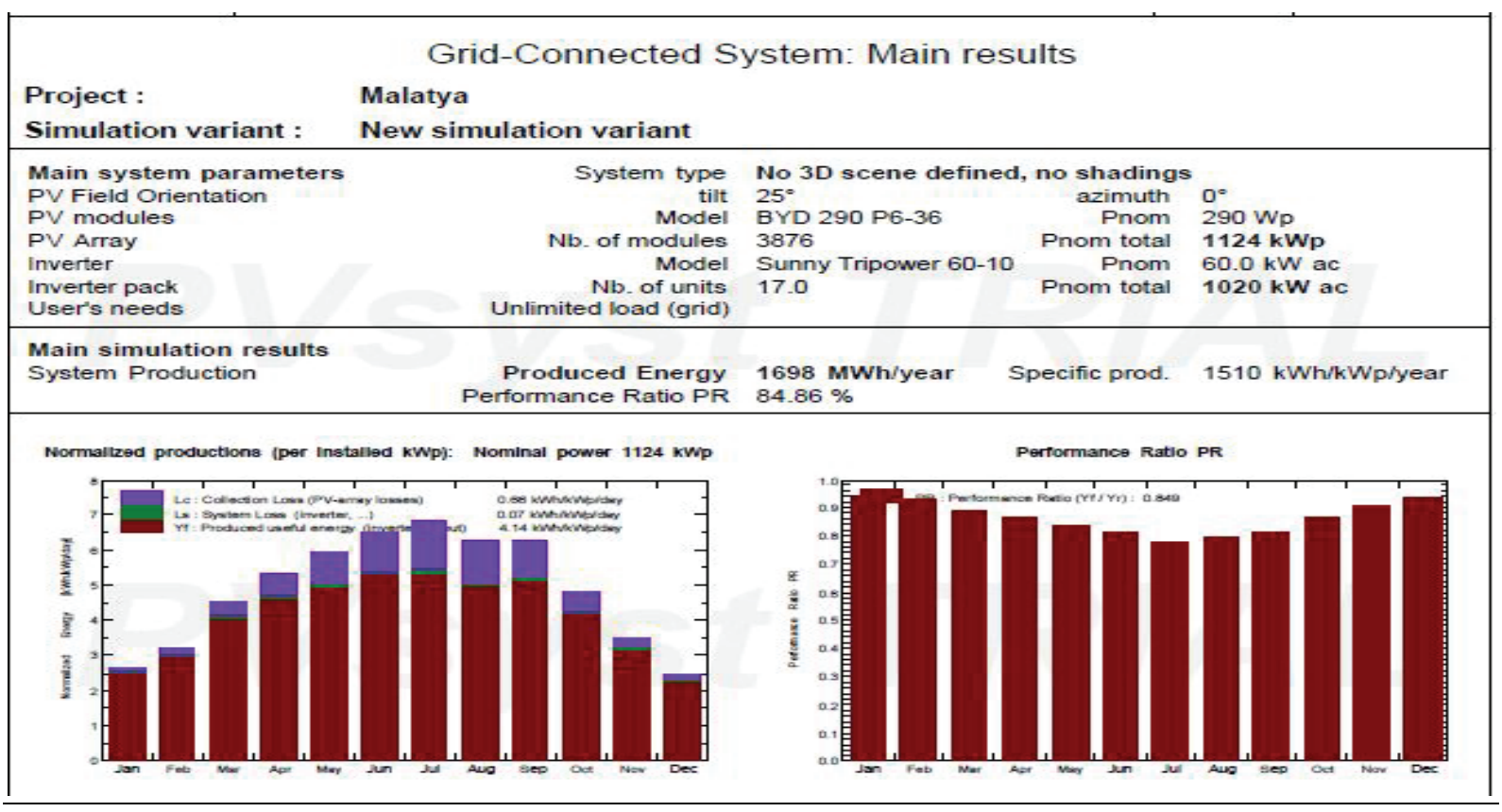

Figure 3. Malatya province PVsyst report.

When the real values were compared with the PVsyst values, the following results were obtained: in February, Malatya power plant reached 72,2 MWh energy production in 21 days. PVsyst predicted energy production value for 28 days scale as $93.9 \mathrm{MWh}$. Proportionally, recorded measurements from the field exceeded the prediction calculated by PVsyst. PVsyst report in this case had an accuracy rate of 97,5\%. Adana power plant produced 71,6 MWh energy in February in 21 days. PVsyst predicted production of energy for this plant to be $93.9 \mathrm{MWh}$ for 28 days. The PVsyst reports overlapped with a high accuracy of $96,8 \%$ with field measurements. For Niğde power plant, 21-day long energy production value was 97,4 MWh. In this case, the predicted value by PVsyst for 28 days was 150,1 MWh. Again, the PVsyst reports overlapped with a high accuracy rate of $86,5 \%$ with field measurements. In March, Malatya power plant produced 114,8 MWh energy. PVsyst predicted 141,5 MWh energy production. For this occasion, the energy production of the plant remained below the predictions of PVsyst. The accuracy of the report was $81,1 \%$ in this case. For Adana power plant, 137,5 MWh energy was produced in March. The predictions of PVsyst reported $132 \mathrm{MWh}$ energy production. For this plant, the produced energy exceeded the predictions by PVsyst. The accuracy rate was reported to be $96 \%$. Niğde power plant produced 156,5 MWh energy in March, while PVsyst predicted an energy production of 183,1 MWh. March energy production of Niğde plant did not meet the predicted value. The accuracy rate of the report was $85,4 \%$ in this case. In April, Malatya power plant reached $188,4 \mathrm{MWh}$ energy production, while the prediction of PVsyst was $155,8 \mathrm{MWh}$. The energy production by Malatya power plant in April exceeded the predicted value by PVsyst, which, in this case, had an accuracy rate of $82,6 \%$. Energy production of Adana power plant in April reached 160,2 MWh. PVsyst program predicted an energy production of 147,9 MWh, which remained below the actual value. The accuracy rate was 92,3\%. Niğde power plant produced 196,6 MWh in April. PVsyst predicted an energy production of 192,3 MWh. The prediction remained slightly below the actual value. The accuracy rate was 97,8\%. For the first 7 days of May, Malatya power plant generated 29,7 MWh energy. Monthly PVsyst prediction was 172,5 MWh for May. The produced energy remained below the predicted value, and the accuracy rate was 73,7\%. For the first 7 days of May, Adana power plant generated 37,2 MWh energy. Monthly PVsyst prediction was 159,3 MWh for May. Proportionally, the energy production remained slightly below the predicted value. The accuracy rate was $99,9 \%$. 
The real value, PVsyst reports, and accuracy rate comparisons are given in Figures 4, 5, and 6. Lastly, for the first 7 days of May, Niğde power plant generated 40,1 MWh energy. Monthly PVsyst prediction was 215,1 MWh for May. The accuracy rate in this case was $80 \%$. When the energy production data from the field was compared to predictions made by PVsyst, it was observed that there were monthly and regional fluctuations in predictions as overlapping, staying below or above the actual values.

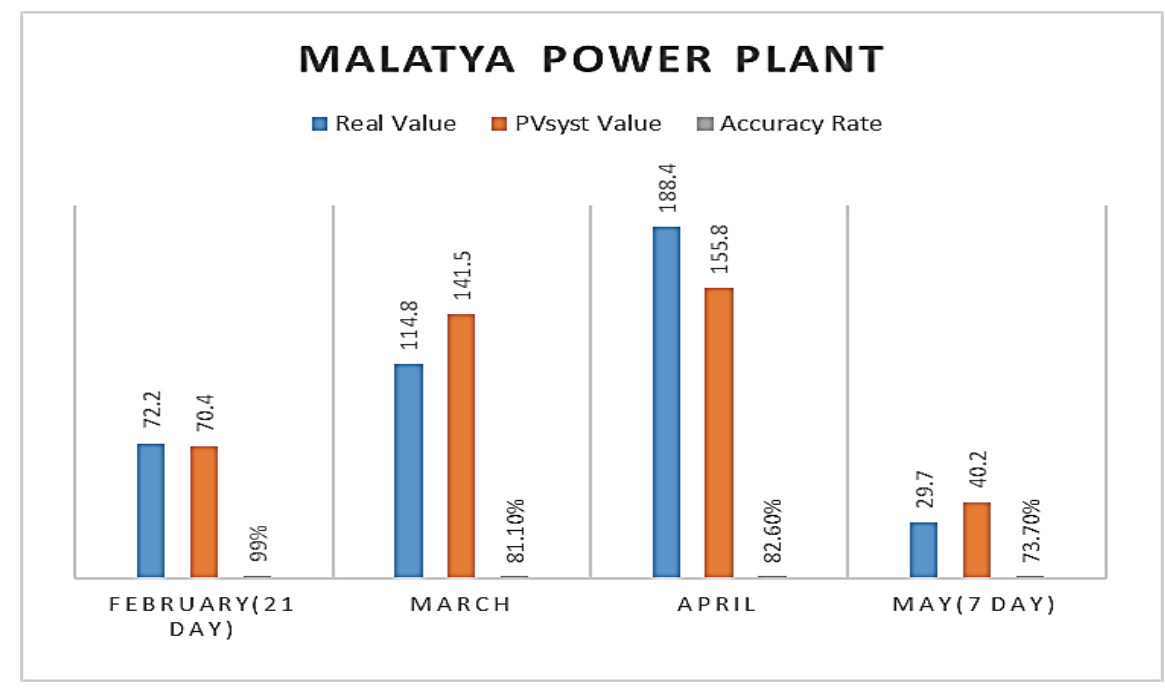

Figure 4. Malatya power plant real-PVsyst production values comparison.

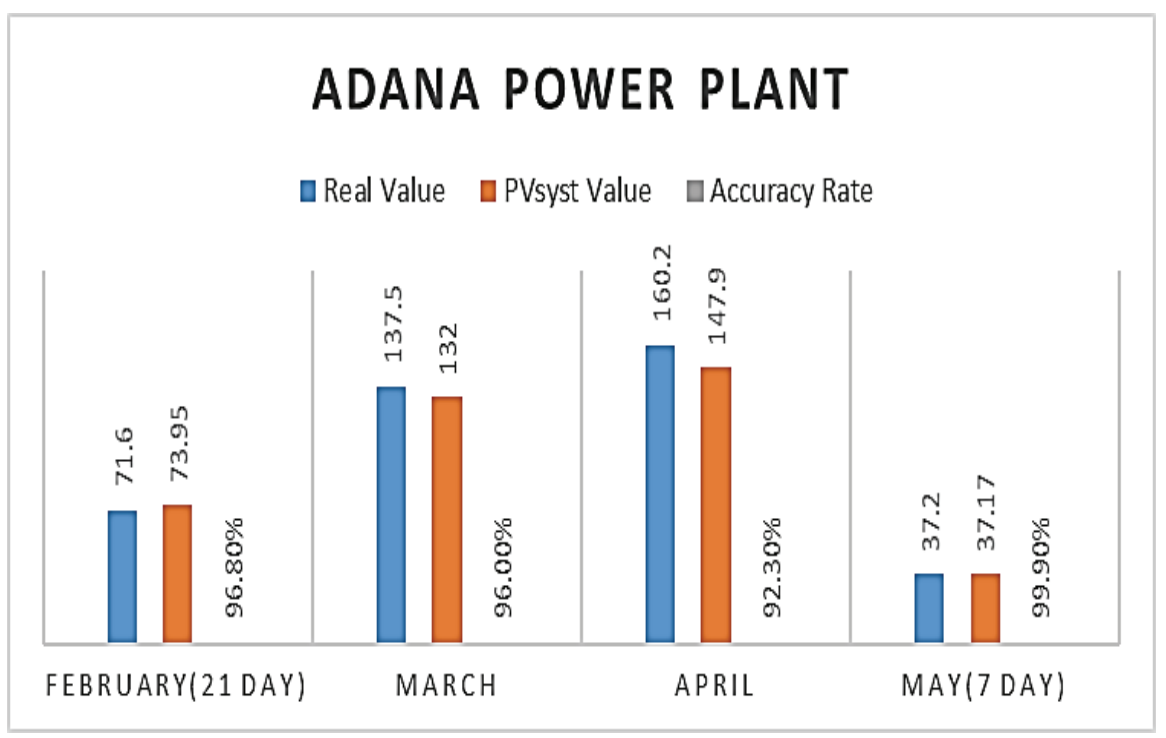

Figure 5. Adana power plant real-PVsyst production values comparison.

These differences arise from the fact that the PVsyst program created the reports in line with the measurements taken over many years. Due to the year to year climate fluctuations corresponding to the month that energy generation data recorded, variations occur between the actual values and the predictions. 


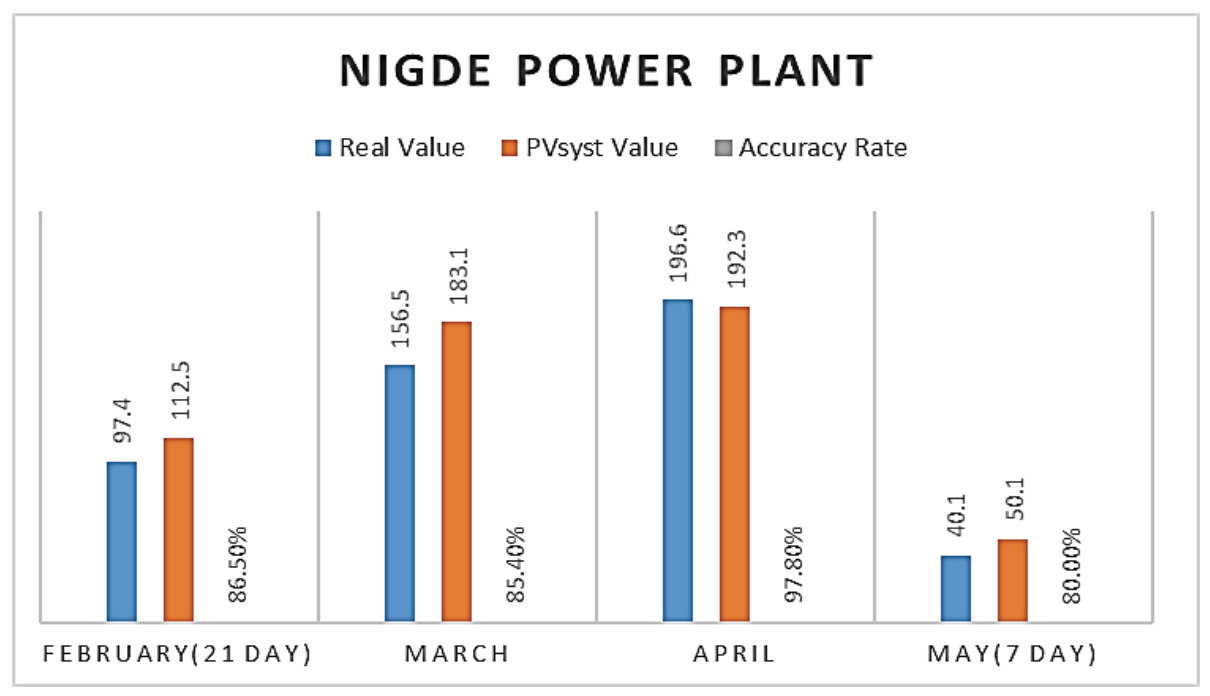

Figure 6. Niğde power plant real-PVsyst production values comparison.

The lowest accuracy rate was recorded as $73.7 \%$, while the highest accuracy rate was $99.9 \%$.

\section{CONCLUSION}

In this study, actual data taken from power plants established in Adana, Malatya, and Niğde provinces of Turkey were compared to PVsyst simulation results to investigate the suitability of the regions for potential investments. According to the comparison of the data obtained on a daily basis, Niğde power plant has reached more production values than Malatya and Adana power plants. Although a general increase in energy production was observed between 7 February and 7 May, daily increases and decreases were recorded due to the climate fluctuations. PVsyst reports analyzed for power plants are concluded to be feasible. The lowest accuracy rate was recorded as $73.7 \%$, while the highest accuracy rate was $99.9 \%$. When the analysis was made for the same time constraints among 3 different power plants, which were produced using the same equipment, established in 3 different regions, Niğde Province was concluded to be the most suitable power plant for investment. Apart from the technical analysis, there was no significant difference in production values of installed power plants. Considering the results of analysis, since there were no significant efficiency differences for the plant installation, investments can be directed considering the proximity to the energy connection point, land investment cost, ease of transportation for logistics, field suitability, and safety. The findings in this study are aimed to be benefited by investors, policy-making authorities, and academic studies. In future studies, performance evaluation calculations can be included in addition to PVsyst reports and actual production values. Thus, real data-simulation data and theoretical data fits can be analyzed. In addition, different regions can be considered for data collection. Optimization-oriented software can be developed, and other power plants can be monitored continuously. Thus, business optimizations can be achieved.

\section{REFERENCES}

Al-Badi AH. 2018. Measured performance evaluation of a $1.4 \mathrm{~kW}$ grid connected desert type PV in Oman. Energy Sustainable Develop; 47:107-13

Andaloussi, Z.J., Raihani, A., Elmagri, A., Bouattane, O., 2020. A New Interconnection Technique for PV Panel Cells using Cubic Topology. Journal of Engineering Research 8(2):145-161 
Ayvazogluyuksel, O. 2016. Solar Energy Analysis of a Home by Considering Outdoor Parameters. M.Sc. Thesis Eskisehir Anadolu University Graduate School of Sciences Electrical and Electronics Engineering Program

Basha, L.S. 2012. Analysis and Evaluation Tools Development of Photovoltaic Modules and System Performance Under Jordanian and German Climatic Conditions. M.Sc. Thesis Kairo University Engineering - Kassel University Electrical and Computer Engineering. Giza, Egypt- Kassel, Germany.

Banda,MH., Nyeinga, K., Okello, D., 2019. Energy for sustainable development performance

evaluation of $830 \mathrm{kWp}$ grid-connected photovoltaic power plant at Kamuzu International Airport-Malawi. Energy Sustainable Develop 51:50-5

Boateng, E. 2016. The Potential Socio Economic and Environmental Impacts of Solar PV Mini-Grid Deployment on Local Communities: A Case Study of Rural Island Communities on The Volta Lake, Ghana. M.Sc. Thesis. Jyvaskyla University Economy and Business Department. Jyvaskylan, Finland.

Bouhouras, A. S., Marinopoulos, A. G., Labridis, D. P. \& Dokopoulos, P. S. 2010. Installation of PV systems in Greece-Reliability improvement in the transmission and distribution system. Electric Power Systems Research 80: 547-555

Cubukcu, M., Gumus, H., 2020. Performance analysis of a grid-connected photovoltaic plant in eastern Turkey. Sustainable Energy Technologies and Assessments 39: 2213-1388.

Dincer, F. 2011. Potential of Electricity Production of Solar Energy in Turkey and Economical Analysis with Comparative Evaluation According to the European Union Countries. KSU Engineering Journal 14(1): 8-17

Gucin, T. 2013. Design and Simulation of Electric Vehicle Fast Charging Station Using Solar and Wind Power. M.Sc. Thesis Istanbul Technical University. Istanbul, Turkey.

Ismail, MS., Moghavvemi, M., Mahlia, TMI., 2013. Characterization of PV panel and global optimization of its model parameters using genetic algorithm. Energy Conversion and Management 73: 10-25.

Ismail, MS., Moghavvemi, M., Mahlia, TMI., 2013. Techno-economic analysis of an optimized photovoltaic and diesel generator hybrid power system for remote houses in a tropical climate. Energy Conversion and Management 69: 163-173.

Kandasamy, C. P., Prabhu, P., and Niruba, K. 2013. Solar potential assessment using PVSYST software. International Conference on Green Computing, Communication and Conservation of Energy (ICGCE). Chennai, India

Karataş, A. 2012. Electrical Energy Production from Solar Energy. M.Sc. Thesis Trakya University. Edirne, Türkiye.

Karki, P., Adhikary, B. \& Sherpa, K. 2012. Comparative study of grid-tied photovoltaic (PV) system in Kathmandu and Berlin using PVsyst. Third International Conference on Sustainable Energy Technologies (ICSET). Kathmandu, Nepal

Khan, M.F.N., Malik, T.N., Sajjad, I.A. 2020. A Novel Probabilistic Generation Model for Grid Connected PV Based Distributed Generation. Journal of Engine. Resear. 8(1):231-247.

Kjaer, SB., Pedersen, JK., Blaabjerg, F., 2005. A review of single-phase grid-connected inverters for photovoltaic modules. IEEE Transactions on Industry Appl. 41(5): 1292-1306

Li, W., He, X., 2011. Review of Nonisolated High-Step-Up DC/DC Converters in Photovoltaic Grid-Connected Applications. IEEE Transactions on Industrial Electronics 58(4): 1239-1250.

Mavsar, P., Sredenšek, K., Štumberger, B., Hadžiselimović, M., Seme, S., 2019. Simplified method for analyzing the availability of rooftop photovoltaic potential. Energie.12(22): 1-17 
Mofijur, M., Mahlia, TMI., Silitonga, AS., Ong HC., Silakhori, M., Hasan, M., Putra, N., Ashrafur Rahman SM., 2019. Phase Change Materials (PCM) for Solar Energy Usages and Storage: An Overview. Energies 12(16): 3167.

Rawat, M.S., Vadhera, S., 2019. A Comprehensive Review on Impact of Wind and Solar Photovoltaic Energy Sources on Voltage Stability of Power Grid Journal of Engineering Research 7(4):178-202

Olmez, Y. 2017. Determination of Solar Power Potential in Turkey and Impact of Solar Power Plant In Karapinar On The Grid. Turkey. M.Sc. Thesis Gazi University Graduate School of

Natural and Applied Sciences. Ankara, Turkey.

Sakdiseth, S. 2015. Potential Electricity Generation from Small Scale Solar Photovoltaic Systems - Case Study 1: Solar Harvesting Potential from roofs of Invercargill Homes and Case Study 2: Model Validation using Existing Data from PV Generation on Selected New Zealand Schools. New Zealand M.Sc. Thesis New Zealand Massey University Engineering and Advanced Technologies İnstitute New Zealand.

Seme, S., Sredenšek, K., Štumberger, B., Hadžiselimović, M., 2019. Analysis of the performance of photovoltaic systems in Slovenia. Sol Energy 180:550-8.

Sharma, Y. \& Chandel, S. S. 2013. Performance analysis of a $190 \mathrm{kWp}$ grid interactive solar photovoltaic power plant in India Energy 55: 476-485.

Yadav, P., Kumar, N., Chandel, S. 2015. Simulation and Performance Analysis of a 1 kWp Photovoltaic System Using PVsyst. International Conference on Computation of Power, Energy, Information and Communication. Tamil Nadu, India. 